\title{
GRANULAR AQUIFER SYSTEM OF WEST CHALKIDIKI AREA, REGION OF CENTRAL MACEDONIA, NORTHERN GREECE
}

\author{
Veranis N. ${ }^{1}$, Nimfopoulos M. ${ }^{2}$, Christidis $\mathrm{C}^{3}$ and Chrysafi A. ${ }^{4}$ \\ ${ }^{1}$ Hydrogeologist, 39 Perraivou st., 543 52, Thessaloniki, Greece, nikosveranis@gmail.com \\ ${ }^{2}$ Environmental Geochemist, IGME, 1 Fragon street, 54626 Thessaloniki,mnimfo@thes.igme.gr \\ ${ }^{3}$ MSc Geologist, christidisc@hotmail.com \\ ${ }^{4}$ MSc Geologist, alexchrysafi@hotmail.com
}

\begin{abstract}
The granular aquifer system of the western Chalkidiki peninsula covers an area of $667 \mathrm{Km}^{2}$ occupying Neogene and Quaternary sediments. The present study deals with the hydrogeological and hydrogeochemical characterization of the granular aquifer system for the purposes of efficient utilization and management of groundwater resources. It is a multilayered formation, composed of unconsolidated to semi-consolidated sands, gravels, conglomerates, sandstones and marly limestones with intercalated impermeable to semi-permeable beds of clays, marls or mixed with pebbles and sands. The aquifer system is characterized by medium to moderate hydrocapacity and the pumped groundwater consumptions are $74 * 10^{6} \mathrm{~m}^{3} / y$ r. Piezometric studies carried out in the period of 2003-14, conclude that the piezometric surface decline is located in the S and SE parts of the aquifer system, while in the rest Central and NW parts there is a noticeable rising of the groundwater table. Groundwater is generally characterized by a good quality; however, groundwaters of the broader Triglia area, have excessively high contents of As (10 to $3400 \mu \mathrm{gr} / \mathrm{l})$ and B $(1.5$ to $4.0 \mathrm{mg} / \mathrm{l})$. Other natural pollutants are Fe and Mn. Salinization and high values of nitrate are mainly detected in water boreholes of Moudania-Portaria, Akrotiri-Epanomi and Agelochori areas.

Keywords: Hydrogeological parameters, piezometric study, groundwater quality.
\end{abstract}

\section{Пврі́̊}

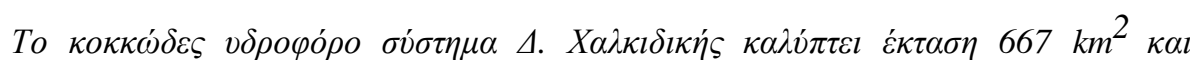

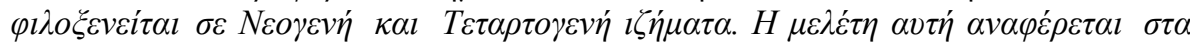

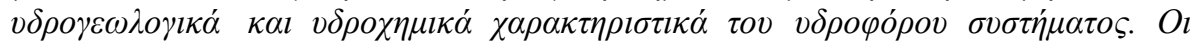

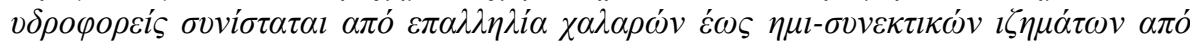

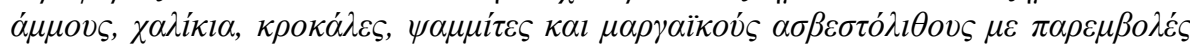

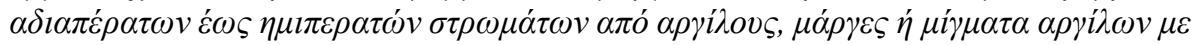

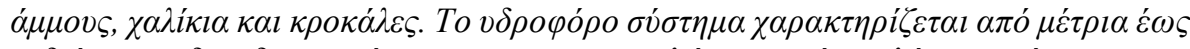

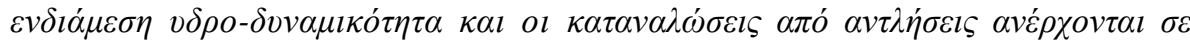

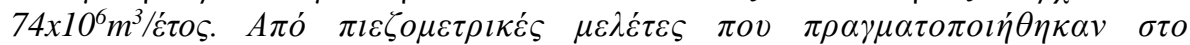

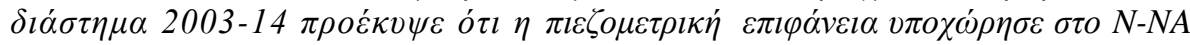

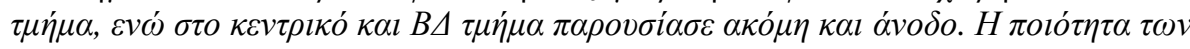




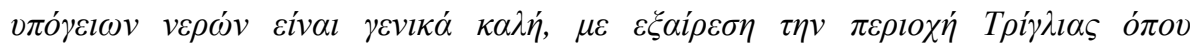

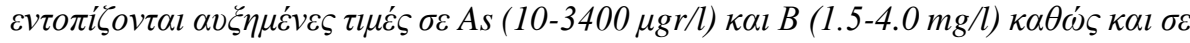

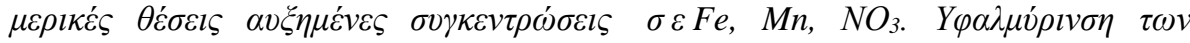

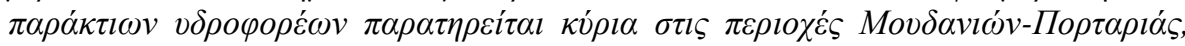

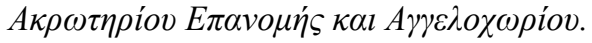

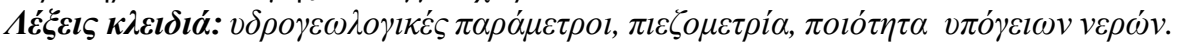

\section{Introduction}

Groundwater is a critical resource for 65000 permanent inhabitants living in the west Chalkidiki area. In addition, 180000 tourists and seasonal inhabitants during summer season use it as potable water, in agriculture, farming and manufacture. Previous hydrogeological studies only refer to some parts of the aquifer system (e.g. Loehnert and Papakonstantinou, 1988; Xefteris, 2000, unpublished reports of IGME).

This work deals with the hydrogeological and hydrogeochemical characterization of west Chalkidiki granular aquifer system aiming to contribute to an efficient utilization and management of groundwater resources. The methodology involves the analysis and interpretation of existing data as borehole logs, pumping tests, static water level measurements, meteorological data, surface water supply measurements, groundwater consumption and chemical analyses of the ground waters samples collected in the period 2004-10 by the Institute of Geology and Mineral Exploration (IGME), (Veranis et al., 2010) and from local authorities in the period 2011-14.

\section{Geomorphology and land uses}

The west Chalkidiki aquifer system covers an area of $667 \mathrm{~km}^{2}$ and is extended from the Megalo Emvolo to the northern part of Kassandra Peninsula and along the west part of the Chalkidiki peninsula. The main part of the aquifer system is plain, with hilly $(200-500 \mathrm{~m})$ and semimountainous $(500-638 \mathrm{~m}$ ) areas. The average elevation of the area is $110 \mathrm{~m}$ ranging from 0 to 638 $\mathrm{m}$. The relief is mature with elongated, U-shaped, dry valleys of crosscutting torrents (Syrides, 1990). Karstified limestones of Mesozoic age, are located in the Katsika mountainous area. They cover a total area of $15 \mathrm{~km}^{2}$ and represent a very intense geomorphologic relief in contrast to the surrounding hilly and flat coastal area. Most part of the area is characterized by a smooth relief, with small to moderate soil slopes $(2-5 \% \mathrm{~S}-\mathrm{SW})$ in the larger part of the area. This fact, has predominantly favored the infiltration process rather than the run off, which only occurs after intense rainfalls. The hydrographic network is of dendrite type and consists of sub-parallel torrents of NNE-SSW general direction. Olynthios river is located in the E part of the aquifer system, being the only stream where the run off occurs for 9 to 10 months per year, with mean water supply of $1400 \mathrm{~m}^{3} / \mathrm{h}$. According to CORINE, from a total area of $667 \mathrm{~km}^{2}$, the agricultural land occupies $534 \mathrm{~km}^{2}(80.06 \%)$. The forest, semi-forest and pasture areas occupy $100.0 \mathrm{~km}^{2}(15.0 \%)$, about $32 \mathrm{~km}^{2}(4.7 \%)$ are covered by the settlements and $0.8 \mathrm{~km}^{2}(0.12 \%)$ are occupied by wetlands.

\section{Geology}

The study area geologically belongs to the Peonia zone and consists of Quaternary and Neogene sediments (Figure 1) with a depositional environment varying from land-river to delta, lake and land type. The total thickness of the sediments ranges from 150 to $500 \mathrm{~m}$ in the higher topographic reliefs and increases to $1000-1500 \mathrm{~m}$ or more $(\max =3500 \mathrm{~m})$ in the coastal areas (Syrides, 1990). Holocene alluvial sediments are located along the torrent beds and coastal valleys. They consist of sands, clay-sands, clays, conglomerates, pebbles and their intercalations. Pleistocene deposits of red-clays are located in the Moudania area and travertines as hot spring aprons are found in Eleochoria area. Pleistocene terrace deposits of unconsolidated recent or old scree and lateral deposits of boulders, conglomerates, clays and their intercalations are located in other places (Figure 1). 
Neogene sediments are divided in: (a) Lacustrine limestones and hard marls. They are found in the W part of Katsika mountain and constitute the upper horizons of the sandstone-marl series. (b) Sandstone-marl series overlie the red clay beds and dominate most of the $\mathrm{W}$ and Central part of the W Chalkidiki peninsula. The stratigraphic succession of the beds is not constant and generally consists of alternating beds of sands, clayey marls, clays, marl-clays with intercalations of semiunconsolidated sandstones, river-bank deposits and sandstone grit. (c) Red clay series, covers the Central and S-SE parts of the aquifer system and consists of red to brick bed clays with mica and fine grained quartz. In places they include lenticular intercalations of sands, marls, travertine, marly limestones and conglomerates. (d) Basal conglomerates series, located at the north margins of the study area, were deposited unconformably to the basement pro-Neogene rocks and usually consist of loose to semi-consolidated conglomerates with intercalations of red beds.

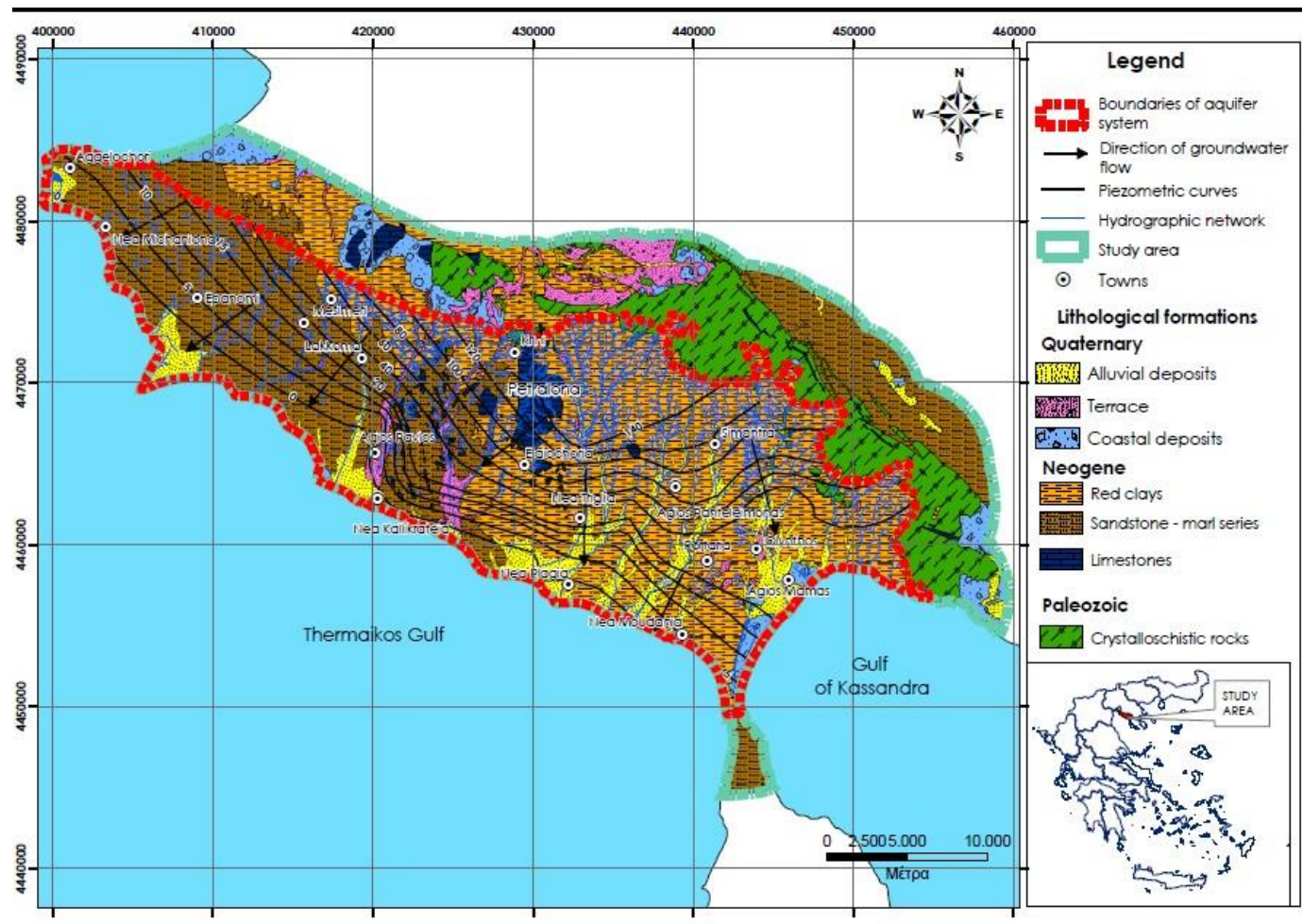

Figure 1 - Simplified geological-hydrogeological map of west Chalkidiki aquifer system.

In the NE part of the aquifer system many boreholes are found penetrating the basal conglomerate series.

The basement rocks (gneisses, schists, ophiolites, limestones, granites) of Paleozoic and Mesozoic age are located in the upper topographic parts along the northern margins of the aquifer system. From the hydrogeological point of view, the most interesting are the Mesozoic karstified limestones of Katsika mountainous area $\left(15 \mathrm{~km}^{2}\right)$. Satellite picture interpretation concludes that the faults have NNW-SSE, NE-SW and N-S directions.

\section{Hydrolithology and hydrogeological parameters}

The aquifer system is a multilayered system that is composed of unconsolidated to semiconsolidated sands, gravels, conglomerates, sandstones, as well as marly limestones or travertine lenses and among them intercalations of impermeable to semi-permeable beds as red clays, silts, green-gray clays, marls or mix of clays with sands, pebbles, gravels and conglomerates. The thick- 
ness and permeability of the unsaturated zone are important parameters for the vulnerability assessment of the aquifer system to contamination sources. The lithological description of the 150 borehole logs reveals that the thickness of unsaturated zone ranges from 10 to $195 \mathrm{~m}$ and the geometric mean value is $45 \mathrm{~m}$. In most part (64\%) of the aquifer system, the unsaturated zone consists of semi-permeable materials as clays, mixed with sands and gravels or intercalations of clay and sand beds. The rest $33 \%$ consists of impermeable materials like red clay beds, marls and 3\% only consists of permeable sediments as gravels, pebbles, sands mixed with a small amount of clays. The percentage contribution of the aquifers in the total thickness of the drilled sediments ranges from 1.5 to $61 \%$ and the mean value is about $28 \%$. The different aquifers range in thickness from0.5 to $50 \mathrm{~m}$ and the total thickness of the aquifer system up to a depth of $500 \mathrm{~m}$ is $140 \mathrm{~m}$, ranging from 10 to $250 \mathrm{~m}$. The boreholes $(\mathrm{n}=150)$ geometric mean values of yield is $40 \mathrm{~m}^{3} / \mathrm{h}(10-140)$, specific capacity $(\mathrm{Sc})$ is $1.50\left(\mathrm{~m}^{3} / \mathrm{h}\right) / \mathrm{m}(0.05-33.3)$, transmissivity $(\mathrm{T})$ is $5.0^{*} 10^{-4} \mathrm{~m}^{2} / \mathrm{s}\left(3.46^{*} 10^{-5}-2.92 * 10^{-}\right.$ $\left.{ }^{2}\right)$ and hydraulic conductivity $(\mathrm{K})$ is $1.56 * 10^{-5} \mathrm{~m} / \mathrm{s}\left(3.30 * 10^{-7}-1.01 * 10^{-3}\right)$ respectively. The most favorable hydrogeological conditions for groundwater resources are located in the area extended between the Epanomi and Agelochori village and the worst among Petralona, Scholari and Lakkoma village. The $\mathrm{N}$ part of the aquifer system extending among Krini, Scholari, Mesimeri, Lakkoma, Gonia, Petralona villages and $\mathrm{N}$ of Simandra village covers a total area of $160 \mathrm{Km} 2$ (Figure 1). It consists of red beds, basal conglomerates, clays, clay-sands, sands, lacustrine limestones with hard marl intercalations and clay-marls with sandstones intercalations. The hydraulic conductivity of these formations is very low $\left(\mathrm{K} \leq 10^{-7} \mathrm{~m} / \mathrm{s}\right)$ and the potentiometric surface is very low (>150 $\mathrm{m}$ from the surface). Even in the deep $(320 \mathrm{~m})$ boreholes, yields are very low $\left(5-10 \mathrm{~m}^{3} / \mathrm{h}\right)$ associated with low values of specific capacity $\left[0.05\left(\mathrm{~m}^{3} / \mathrm{h}\right) / \mathrm{m}\right]$. There, the groundwater quality is inhibiting its use as drinking water.

Pumping test data and the associated piezometric study revealed that the aquifer system is varied from semi-confined to confined. Intense permeability variations characterize different strata either in vertical or in horizontal dimension. This is attributed to grain size distribution of the materials and the varying degrees of diagenesis process. Permeable sediments such as unconsolidated deposits of sands and pebbles with hydraulic conductivity $(\mathrm{k})$ ranging from $10^{-3}$ to $10^{-4} \mathrm{~m} / \mathrm{s}$, semi- permeable sediments as consolidated conglomerates, sands, sandstones and marly limestones have intermediate hydraulic conductivity ranging from $10^{-4}$ to $10^{-7} \mathrm{~m} / \mathrm{s}$. The marls, clays or mixtures of them with sands and pebbles have a very low permeability or are almost impermeable materials $\left(\mathrm{k}=10^{-7}\right.$ to $10^{-}$ $\left.{ }^{9} \mathrm{~m} / \mathrm{s}\right)$. According to their hydrolithological behavior and hydrogeological potential the different geological formations of the study area are divided into the following classes (Figure 1).

(a) Micro pore permeable alluvial formations covering large areas and having a low resource potential. They consist of alluvial fans, lake deposits of Holocene and Pleistocene river-torrent deposits that overlie the Neogene sediments and are crossing the area of the aquifer system. Sections across the alluvial fans show that they are lenticular in shape resulting in small thickness elongated layers along the direction of the watercourses. The grain size is continuously decreased from upstream to downstream and, in the same direction the thickness of the permeable strata is also decreased. Alternations of clays, silts, sands, pebbles, gravels or a mixture of them can be observed in these areas. Red clay beds, mixed with gravels, pebbles and sands (10-25 m in thickness) compose most part of this formation. Due to lateral changes in the grain size composition of the sediments and the presence of clay materials, the hydraulic conductivity of the formations varies from $10^{-4}$ to $10^{-7} \mathrm{~m} / \mathrm{s}$. The aquifers are mostly composed of gravels, sands and conglomerates, and are mainly located in the downhill parts of the streams. The aquifer materials have an effective porosity ranging from 10 to $22 \%$. Their hydrogeological interest is considered important because they cover an area of $87 \mathrm{~km}^{2}$ and allow a high infiltration about $10-20 \%$ of the precipitation. They also provide favorable conditions for the development of groundwater potential in the underlying Neocene aquifers. They are recharged from direct percolation of precipitation $(46-92 \mathrm{~mm} / \mathrm{yr})$ or by percolation of surface waters that were once stored within the alluvial formations moving downwards to deep Neogene aquifers. Shallow boreholes located in this hydrolithological 
formation yield 10 to $30 \mathrm{~m}^{3} / \mathrm{h}$, but due to over-pumping in the last decades the alluvial aquifers have been largely depleted in many places.

(b) Micro to macro-porous semi-permeable Neogene formations of large area and moderate potential. They cover an area of $235 \mathrm{~km}^{2}$ in the Central and NW part of the aquifer system (Figure 1). The formations belong to sandstone-marl series and consist of alternating beds of clays, clay- sands, sands, clay-marls with intercalations of sandstones, conglomerates and marly limestones. The recharge of the aquifers is by infiltration of precipitation $(46 \mathrm{~mm} / \mathrm{yr})$, surface water percolation along the torrent beds and lateral infiltration of karst aquifer of Katsika area. The hydraulic conductivity of the different formations ranges from $10^{-4}$ to $10^{-7} \mathrm{~m} / \mathrm{s}$ depending on the grain size and clay content. Borehole yields range from 20 to $140 \mathrm{~m}^{3} / \mathrm{h}$ with mean value of $40 \mathrm{~m}^{3} / \mathrm{h}$. The specific capacity (Sc) values range from 0.5 to $12\left(\mathrm{~m}^{3} / \mathrm{h}\right) / \mathrm{m}$, transmissivity (T) ranges from $1.67 * 10^{-4}$ to $1.3 * 10^{-3} \mathrm{~m}^{2} / \mathrm{s}$ and aquifers hydraulic conductivity (K) from $3.30 * 10^{-6}$ to $8.0 * 10^{-5} \mathrm{~m} / \mathrm{s}$.

(c) Impervious to low permeability Neogene and Pleistocene microporous formations covering a large area and of moderate to low potential in the underlying aquifers. These formations occupy an area of $348 \mathrm{~km}^{2}$ and are mainly situated in the Central, S and E part of the aquifer system (Figure 1). They consist of red to brick bed clays and in places they include lenticular intercalations of sands, marls, travertine, marly limestones and conglomerates. The red beds have a grain size less than $2 \mu \mathrm{m}$ in $50 \%$ of the material and the hydraulic conductivity is very low $\left(\mathrm{k} \leq 10^{-7} \mathrm{~m} / \mathrm{s}\right)$. Borehole yields range from 10 to $80 \mathrm{~m}^{3} / \mathrm{h}$ with a mean value of $25 \mathrm{~m}^{3} / \mathrm{h}$. The higher borehole yields $\left(40-80 \mathrm{~m}^{3} / \mathrm{h}\right)$ are usually found in the coastal area where the Neogene aquifers are also recharged by runoff infiltration through the Quaternary deposits and the lower yields $\left(10-25 \mathrm{~m}^{3} / \mathrm{h}\right)$ in the topographic uphill areas, close to contact with the basement rocks. The specific capacity $(\mathrm{Sc})$ values range from 0.05 to $1.75\left(\mathrm{~m}^{3} / \mathrm{h}\right) / \mathrm{m}$ with a geometric mean value of $0.4\left(\mathrm{~m}^{3} / \mathrm{h}\right) / \mathrm{m}(\mathrm{n}=50)$. Transmissivity $(\mathrm{T})$ ranges from $1.54 * 10^{-5}$ to $9.51 * 10^{-4} \mathrm{~m}^{2} / \mathrm{s}$ and the geometric mean value is $1.50 * 10^{-4} \mathrm{~m}^{2} / \mathrm{s}$. Pumping tests revealed that correlation between $\mathrm{T}$ and $\mathrm{Sc}$ parameters is: $\mathrm{T}=1.09 *(\mathrm{Sc})^{1,11},\left(\mathrm{R}^{2}=0.89\right.$, $\mathrm{n}=15$ ), where $\mathrm{T}$ and $\mathrm{Sc}$ values are expressed in $\mathrm{m}^{2} /$ day. This relationship for transmissivity values $\leq 40 \mathrm{~m}^{2} /$ day gives approximately similar results with the known empirical relationship of Logan $(\mathrm{T}=1.22 * \mathrm{Sc})$, which is generally applied for confined granular aquifers. The average total thickness of the aquifers is $143 \mathrm{~m}$ (78-228). They comprise about $40 \%$ (28-59) of the drilled layers (200$500 \mathrm{~m}$ ). The aquifers average hydraulic conductivity $(\mathrm{K})$ is $8.74 * 10^{-7} \mathrm{~m} / \mathrm{s}$, ranging from $9.1 * 10^{-}$ ${ }^{8}$ to $5.66^{*} 10^{-6} \mathrm{~m} / \mathrm{s}$. The water resource potentiality of this formation is considered relatively low when compared to neighboring areas in the NW portion of the aquifer system.

\section{Piezometry and hydrological balance}

Systematic piezometric measurements were carried out by IGME in intervals of the period 19832000 on 27 irrigation boreholes and 2004-2008 on 99 irrigation boreholes respectively (Veranis et al. 2010). On the frame of this study, piezometric measurements were also conducted in October 2014. The depth of the PS ranges from 0.9 to $195 \mathrm{~m}$ and the geometric mean value is $33.62 \mathrm{~m}$. The higher depths (138-195 m) of the PS are found in the NE to E part (Agios Panteleimonas- SimantraOlynthos villages area) and in the $\mathrm{N}$ part (Lakkoma-Scholari-Petralona villages area) of the aquifer system and the lower depths $(0.9-10 \mathrm{~m})$ in the coastal areas. The PS ranges between -38 to $+165 \mathrm{~m}$ a.s.l. and the geometric mean value is $0.35 \mathrm{~m}$ a.s.l. The inter-annual variation (ds) of the PS per borehole ranges from 0.43 to $15.0 \mathrm{~m}$, the values also follow the lognormal distribution with a geometric mean value of $\mathrm{ds}=3.20 \mathrm{~m}( \pm 2.2)$. The rate of the inter-annual fluctuations (ds) varies depending on the region. In order to estimate the mean value of ds we have estimated the area of influence for each borehole by Thiessen polygons. During the period 2004-08, no important decline was observed in the area (A), except in the Akrotiri coastal area of Epanomi. On the contrary, in the areas (B) and (C) we have estimated a decline of $0.2 \mathrm{~m} / \mathrm{yr}$ and $0.6 \mathrm{~m} / \mathrm{yr}$ respectively. In case that 
we don't take into account the PS decline which is attributed to abstractions of the permanent reserves, the real mean value of ds is $2.90 \mathrm{~m}$ (Table 1).

Table 1 - Inter-annual real fluctuations of the potentiometric surface (period 2003-08).

\begin{tabular}{|l|l|l|l|l|}
\hline $\mathbf{a} / \mathbf{a}$ & \multicolumn{1}{|c|}{ Area } & \multicolumn{1}{|c|}{ Area $\left(\mathbf{k m}^{\mathbf{2}}\right)$} & \multicolumn{1}{|c|}{ Mean(m) } & \multicolumn{1}{|c|}{ Range(m) } \\
\hline A & Agelochori to Ag. Pavlos & 140 & 1.70 & $0.5-6.0$ \\
\hline B & Ag. Pavlos-Gonia to Ag. Panteleimonas- Flogita & 150 & 3.3 & $0.9-15.0$ \\
\hline C & $\begin{array}{l}\text { Ag. Panteleimonas- Flogita-Moudania to } \\
\text { Agios Mammas-Kalyvia }\end{array}$ & 220 & 3.4 & $1.3-9.0$ \\
\hline & Total area & 510 & $\mathrm{X}=2.9$ & \\
\hline
\end{tabular}

According to piezometric measurements conducted by IGME in the period 1986-2000, it resulted that PS underwent a constant downturn and the mean value was $0.72 \mathrm{~m} / \mathrm{yr}$ ( $\mathrm{n}=16$ boreholes) ranged from 2.5 to $0.08 \mathrm{~m} / \mathrm{yr}$ per borehole. In the period 2003-08, upwards trends have been noticed in many boreholes, mainly situated in the Central and NW part of the aquifer system, covering a total area of $285 \mathrm{~km}^{2}$ or $56 \%$ and the mean PS value is $1.10 \mathrm{~m} \mathrm{(n=54).} \mathrm{On} \mathrm{the} \mathrm{contrary,} \mathrm{in} \mathrm{E-SE} \mathrm{and}$ partially in the Central parts, we noticed a decline of the PS with a geometric mean value $0,97 \mathrm{~m}$ ( $\mathrm{n}=40$ boreholes) covering an area of $235 \mathrm{~km}^{2}$ corresponding to $46 \%$ of the aquifer system with exploitable groundwater reserves $\left(\mathrm{E}=510 \mathrm{~km}^{2}\right)$.

Specifically, the areas where a decline of PS observed are: (a) Agios Pavlos- Kallikratia- SilataEleochoria, (b) Triglia-Agios Panteleimonas-Simantra-Dionysiou, (c) Agios Mammas-OlynthosKalyvia and (d) Akrotiri coastal area of Epanomi. These differences in the behavior of the PS are attributed to different pressures applied to the aquifers due to intense pumping of a considerable number irrigation and drinking water boreholes and differences in recharging rate. Static water level measurements carried out in irrigation boreholes in the $\mathrm{S}$ part of the aquifer system during the period $2008-14$, point to a gradual decline $(0,5-1,5 \mathrm{~m} / \mathrm{yr})$ but data are not enough for the rest of the area of the aquifer system in this period. The reversal in the trend of the PS from reduction in the period 1985-2000 to rising during 2003-08 in many boreholes could be explained by rainfall increase in the period 2003-08 in relation to the period 1986-2000 and de- crease in consumption of irrigation water (Veranis et al., 2010).

According to the groundwater flow contours, the water flow approximately follows the slope of the topographical relief (Figure 1). The geomorphology directly affects the shape of the piezometric contours by shaping curved and concave forms. The convergent and divergent contours are also associated to the hydraulic characteristics of the aquifer system, the recharge and pressure of the abstractions. The aquifer system on a broader scale is considered to be homogenized regarding the hydraulic conductivity values in various directions and the directions of subsurface flow are plotted perpendicular to the piezometric curves. The piezometry shows a general flow direction from NE to SW for the larger part of the aquifer system (Figure 1).

In the NW part of the aquifer system, extending between Iraklia and Agelochori villages, the hydraulic gradient (i) is small and ranges from 0.002 to 0.0072 . In this region, the piezometric contours are invariably parallel to each other and this is attributed to unchanging hydraulic properties of the aquifers. There doesn't seem to be a strong influence on aquifer recharge by runoff percolation or discharge along the stream beds. Low values on the hydraulic head make the aquifer system vulnerable to the intrusion of seawater, and up to date the salinization was detected in Agelochori and Akrotiri Epanomi coastal areas. In Lakkoma, Agios Pavlos and Kallikratia area the hydraulic gradient is 0.005. Higher gradients (0.012- 0.015) are observed in the area between Agios PavlosKallikratia-Gonia and Silata area, as well as in the area between Triglia and Tenedos up to the coastal area of Flogita village. In this area the piezometric curves have shapes associated with the topographic relief. Along the stream valleys the hydraulic gradient has reduced due to water pumping from a considerable number of irrigation boreholes. The curved surfaces of contours in the area downhill of the Katsika are attributed to geomorphology and recharge from the karstic 
aquifer by lateral infiltration (Figure 1). Within the coastal zone of Plagia and Flogita up to Tenedos area the contours are convex. This is attributed to the topographic relief and the numerous irrigation boreholes which caused the decline of the PS. The average hydraulic gradient of PS along the axis Agios Panteleimonas-Zografou villages is 0.010 . Elevated values ( $\mathrm{i}=0.013$ ) are found in the hilly area (altitude 100-240 m) and lower (i=0.003) in lowland coastal area respectively.

During the last decades, the pressures due to water pumping were particularly intense and resulted in PS decline, creating negative absolute elevations ( $\max =-38 \mathrm{~m}$ a.s.1.) in the area of Portaria, Zografou, Dionysiou beach and Flogita villages, where we also have noticed a reverse direction of the hydraulic gradient (Figure 1). This procedure has resulted in aquifer contamination in the area between Zografou and Dionysiou Beach due to mixing with sea water up to a distance of $2.5 \mathrm{~km}$ from the coastline. In the $\mathrm{E}$ part of the aquifer system, the direction of groundwater flow is from NNW to SSE and is parallel to the bed of Olynthios river (Figure 1). The hydraulic gradient ranges from 0.013 to 0.015 . Although the aquifer system is recharged by runoff percolation $\left(5.5^{*} 10^{6} \mathrm{~m}^{3} / \mathrm{yr}\right)$ along the bed of Olynthios river, due to great inclination of the main stream $\left(25 \%_{0}\right)$ and the pressures from the abstractions, the equal potentiometric curves are of concave form and salinization occurs in the coastal area aquifers of Agios Mammas and Kalyvia villages.

Due to intense long time pumping in drinking water wells and in some of the irrigation boreholes, permanent cones of depression were created. Even after pumping stops, due to mingling of the clay or marl layers, a long time (ranging from 2 to 6 months or more) is required to restore the potentiometric surface to the former static level. The greater pressures to the aquifer system were applied by irrigation and drinking water wells during the summer season, the period when the aquifer's recharge by the infiltration and run of percolation are low and simultaneously the PS is at lower level. This procedure favors in many places the intrusion of sea water (salinization) in the coastal areas and, thus deteriorating the groundwater quality. In some places (Agelochori, Akrotiri Epanomi, Agios Pavlos, Flogita-Moudania and Ag. Mamma-Kalyvia) the PS decline has caused a dramatic elimination or a total interruption of the previous aquifer natural discharge to the sea water.

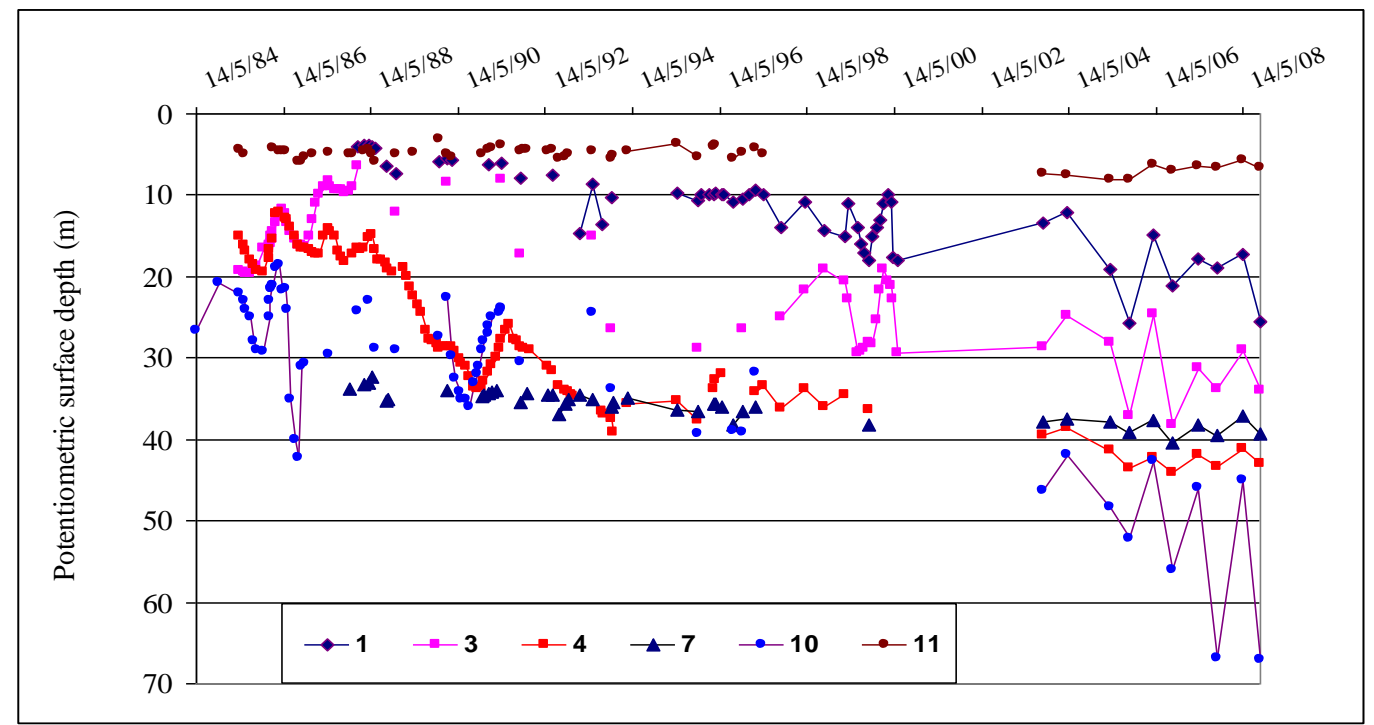

Figure 2 - Fluctuations of the piezometric surface in the period 1984-2008 of TrigliaMoudania area of west Chalkidiki aquifer system.

Inflows: The water balance study is referred to the period 2004-08, because systematic static level measurements of the 99 boreholes are available for this time interval only. Data interpretation of the broader area (Agios Mammas, Agios Pavlos, Mikra, Loutra Thermi and Polygyros) meteorological stations reveals that, the average annual precipitation of the aquifer system area 
during the period 2002-08 is $458 \mathrm{~mm}$ and the mean annual temperature is $15.82{ }^{\circ} \mathrm{C}$. Average annual real evapotranspiration represents $83 \%$ of total annual precipitation and amounts to 380 $\mathrm{mm} / \mathrm{yr}$. (Veranis et al., 2010). The sum of infiltration plus runoff is $78 \mathrm{~mm} / \mathrm{yr}$ or $52.3 * 10^{6} \mathrm{~m}^{3} / \mathrm{yr}$.

The mean value of the infiltration based on the distribution of the rock outcrops in the geological map and the coefficient of infiltration for each rock type (Soulios, 2004) is $41 \mathrm{~mm} / \mathrm{yr}(9 \%)$. Runoff is calculated from the equation of water balance and is $37 \mathrm{~mm} / \mathrm{yr}(8 \%)$. Since limited amounts of surface water arrive to the coast, apart from the direct infiltration $\left(27.4^{*} 10^{6} \mathrm{~m}^{3} / \mathrm{yr}\right)$, the recharging of the aquifer system occurs through surface waters percolation of Olynthios river $\left(5.5^{*} 10^{6} \mathrm{~m}^{3} / \mathrm{yr}\right)$, along the streams beds located in the aquifer system $\left(24.9 * 10^{6} \mathrm{~m}^{3} / \mathrm{yr}\right)$ and from surface water $\left(2.7 * 10^{6} \mathrm{~m}^{3} / \mathrm{yr}\right)$ originating from the Vavdos mountainous area and crosscutting the aquifer system. The total surface water quantities infiltrated to the aquifers system are $31.2 * 10^{6} \mathrm{~m}^{3} / \mathrm{yr}$ ). The aquifer system also enriched by lateral subsurface filtration of the Katsika karst area with $3.0^{*} 10^{6}$ $\mathrm{m}^{3} / \mathrm{yr}$. Irrigation water quantities returning to the aquifer system are estimated about $8.5^{*} 10^{6} \mathrm{~m}^{3} / \mathrm{yr}$ and correspond to $10-15 \%$ of the abstractions. Total inflows to the aquifer system are estimated to be $72 * 10^{6} \mathrm{~m}^{3} / \mathrm{yr}$.

Inflows were also estimated using the equation (1) for renewable reserves estimation: $\mathrm{V}=\mathrm{E}^{*} \mathrm{ds} * \mathrm{n}_{\mathrm{e}}$,

Where, $E=$ the area of the aquifer system with productive boreholes, ds=mean value of the interannual static water level fluctuations. According to data from the lithology description of 150 borehole $\operatorname{logs}$, the aquifers consist of unconsolidated to semi-consolidated sands, conglomerates, sandstones and less of marly limestones and travertine lenses. The cementing materials are fine sands, silts and clays. According to bibliography (Wolf, 1982) the mean value for the effective porosity (ne) of these materials are estimated about $5 \%$.

$\mathrm{V}=510 \mathrm{~km}^{2} * 2.9 \mathrm{~m} * 0.05=74 * 10^{6} \mathrm{~m}^{3} / \mathrm{yr}$

Water pumping: For drinking water purposes consumptions are $14.0 * 10^{6} \mathrm{~m}^{3} / \mathrm{yr}$, and for livestock and other uses $0.4 * 10^{6} \mathrm{~m}^{3} / \mathrm{yr}$. In earlier studies it was referred that, for the irrigation of 118.000 acres (in the year 2001) the pumped groundwater quantities were about $69 * 10^{6} \mathrm{~m}^{3} / \mathrm{yr}$; this corresponds to $585 \mathrm{~m}^{3} / \mathrm{acre} / \mathrm{yr}$ but $10-15 \%$ of the irrigation water returns back to the aquifers (ENM and Consulters 2008). The total water pumping reserves of the system are approximately estimated to be $74 * 10^{6} \mathrm{~m}^{3} / \mathrm{yr}$. Although inputs are approximately equal to outputs, due to differential recharge rates and pressures applied from water pumping in the different parts of the aquifer system, we observed a decline of the PS in some parts and rise in others respectively. The discharges of the groundwater to the sea are estimated $1.5^{*} 10^{6} \mathrm{~m}^{3} / \mathrm{yr}$ and the inflows of seawater to the land about $1.0 * 10^{6} \mathrm{~m}^{3} / \mathrm{yr}$ (Veranis et al., 2010).

\section{Groundwater quality and contamination}

In order to assess groundwater quality of the aquifer system, we evaluated hydrochemical data from previous studies carried out by IGME in the period 2003-10 (Veranis et al., 2010), while in the period 2011-14 chemical analyses were carried out by local authorities in samples collected from drinking water boreholes only. The water samples were collected in dry and wet periods and at least two samples correspond in each borehole.

The $\mathrm{pH}$ values of the groundwater vary between 6.62 and 8.75 with an average of 7.84 which indicates the alkaline nature of groundwater of the study area. In about $96 \%$ of the collected samples, the $\mathrm{pH}$ values are within the permissible range of 6.5 to 8.5 established for drinking water by the Directive 98/83/EC/3. Electrical Conductivity (EC) ranges from 369 to $7182 \mu \mathrm{S} / \mathrm{cm}$ at $25^{\circ} \mathrm{C}$, with a geometric mean value of $887 \mu \mathrm{S} / \mathrm{cm}$. In only $3 \%$ of the boreholes, the EC values were above the maximum permissible limit $(2500 \mu \mathrm{S} / \mathrm{cm})$ for the potable water. 
The geometric mean value of the total hardness is $358 \mathrm{mg} / \mathrm{l}$ and ranges from 60 to $1536 \mathrm{mg} / \mathrm{l}$ (as equivalent $\mathrm{CaCO}_{3}$ ). In $3 \%$ of the boreholes, the values of total hardness are less than $150 \mathrm{mg} / \mathrm{l}$ (medium hardness waters), in $25 \%$ they range from 150 to $300 \mathrm{mg} / \mathrm{l}$ (hard waters) and in $72 \%$ they are more than $300 \mathrm{mg} / \mathrm{l}$ (very hard waters). High hardness values (> 500 mg/l) represent $18.5 \%$ of the analyzed samples and attributed to salinization process or mixing with geothermal waters of the karst. Elevated concentrations of calcium, magnesium, sodium and potassium are attributed to contamination by sea water or mixing with geothermal waters. The increased values of magnesium (60-180 mg/l) located in some of the coastal areas are associated with sea water contamination and in the NE part of the aquifer system are attributed to the ophiolites weathering products mixed with the sediments.

The mean concentration of the cations is in the order $\mathrm{Mg}>\mathrm{Na}>\mathrm{Ca}^{+}>\mathrm{K}$, while those of the anions $\mathrm{i}$ $\mathrm{HCO}_{3}>\mathrm{Cl}>\mathrm{SO}_{4}>\mathrm{NO}_{3}$ respectively. The ratio $\mathrm{HCO}_{3} / \mathrm{SiO}_{2}$ ranges from 5.5 to $94(\mathrm{n}=121$ boreholes). In only 6 samples the values are less than 10, indicating ubiquitous weathering. In 115 samples, the $\mathrm{HCO}_{3} / \mathrm{SiO}_{2}$ ratio ranges from 10 to 94 indicating the prevalence of carbonate rather than silicate weathering and the recharge zone is at a small distance (Hounslow, 1995).

Depending on, (a) the local lithological variations, (b) ion exchange reactions, (c) the time of the groundwater remaining in contact with rock materials, (d) sea water or geothermal waters contamination, different types of groundwater are detected. Hydrochemical data interpretation using the software AquaChem indicated that the most dominant (41\%) water-type is Na-Mg-Ca$\mathrm{HCO}_{3} \pm \mathrm{Cl} \pm \mathrm{SO}_{4}$. In $21 \%$ of the analyzed samples the magnesium ions prevail and the water-type is $\mathrm{Mg}-\mathrm{Ca}-\mathrm{Na}-\mathrm{HCO}_{3} \pm \mathrm{Cl} \pm \mathrm{SO}_{4}$. In $24 \%$ of the samples the calcium ions prevail and the water-type is $\mathrm{Ca}-\mathrm{Mg}-\mathrm{Na}-\mathrm{HCO}_{3} \pm \mathrm{Cl} \pm \mathrm{SO}_{4}$. The water types as $\mathrm{Ca}-\mathrm{Mg}-\mathrm{HCO}_{3}$ or $\mathrm{Mg}-\mathrm{Ca}-\mathrm{HCO}_{3}$ corresponds to $10 \%$ of the samples indicating a meteoric origin of the groundwaters with small retention time. The rest $4 \%$ of the samples correspond to different water-types, such as $\mathrm{Mg}-\mathrm{HCO}_{3}, \mathrm{Mg}-\mathrm{Ca}-\mathrm{Cl}, \mathrm{Na}-\mathrm{HCO}_{3}-$ $\mathrm{Cl}, \mathrm{Mg}-\mathrm{Ca}-\mathrm{Na}-\mathrm{Cl}$ and are usually associated with sea water contamination. Graphic chemistry presentation of the water samples by Piper and Durov diagrams is given in Figure 3.

Chlorine content ranges from 14.1 to $3085 \mathrm{mg} / \mathrm{l}$ and the geometric mean value is $92.2 \mathrm{mg} / \mathrm{l}$. In $90 \%$ of the boreholes, the chlorine content is less than $250 \mathrm{mg} / \mathrm{l}$ (the upper permissible level for the drinking water). Elevated concentrations of chlorine (250-3085 mg/l) are attributed to contamination with sea water in the coastal areas of Agelochori, Akrotiri-Epanomi, Agios Pavlos, Moudania- Portaria and Agios Mammas-Kalyvia. High contents of chlorine (200-303 $\mathrm{mg} / \mathrm{l})$ were also detected in the Tenedos -Triglia-Silata area and are attributed to contamination by geothermal waters which laterally infiltrate from the Katsika karst area to the neighboring fresh water granular aquifers. Sporadic elevated values of chlorine (200-330 mg/l), which were determined in irrigation bore- holes of the Gonia area, are associated to the disposal of untreated waste of domestic origin or farming installations to hydrographic network.

Nitrate $\left(\mathrm{NO}_{3}\right)$ content ranges from 0.1 to $215 \mathrm{mg} / \mathrm{l}$ and the geometric mean value is $9.3 \mathrm{mg} / \mathrm{l}$ $(\mathrm{n}=220)$. In $25 \%$ of the boreholes, nitrate content is $3.97 \mathrm{mg} / \mathrm{l}$, in $75 \%$ of the samples is $26.4 \mathrm{mg} / \mathrm{l}$ and values more than $50 \mathrm{mg} / \mathrm{l}$ correspond to $6 \%$. In $21.6 \%$ of the sampled boreholes the nitrate values are exceeding the threshold value $(\mathrm{TV})=(50+9.3) / 2=29.6 \mathrm{mg} / \mathrm{l} \mathrm{NO}$. In case that nitrate concentrations are more than the TV75 value (in our case TV $75=22 \mathrm{mg} / \mathrm{l}$ ) as defined by EU 2000/60 (article 17.2a \& 17.2b) and the Daughter Guide 2006/118/EU measures must be taken in order to eliminate the nitrate increase (Veranis et al., 2010). 

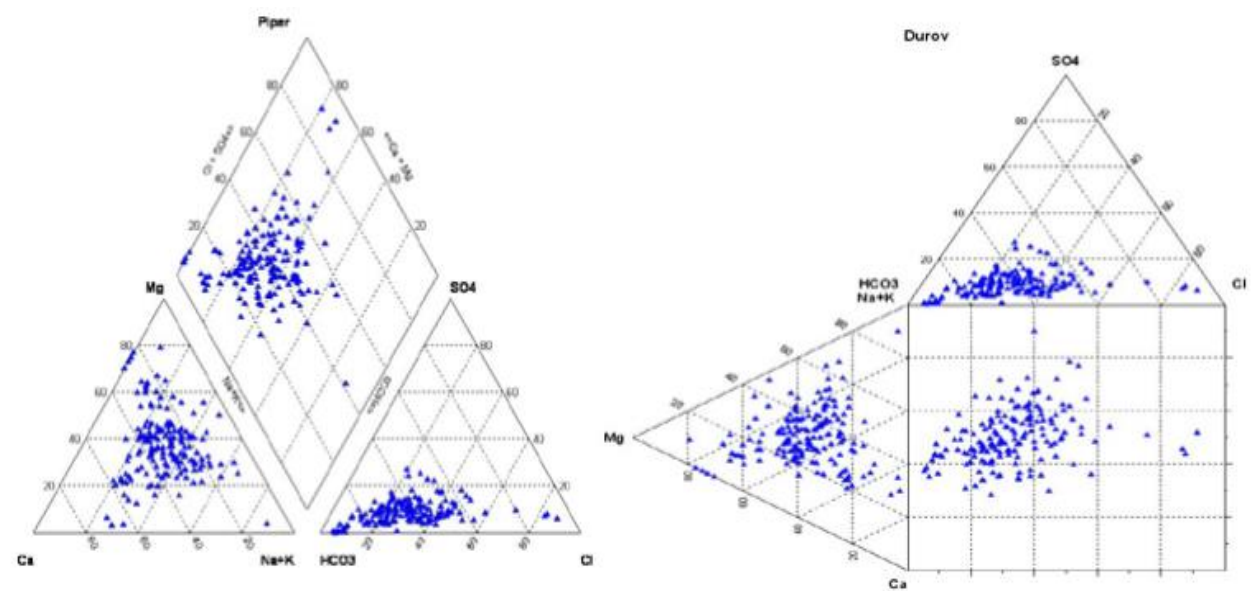

Figure 3 - Graphical representation of the chemistry of the water samples in Piper and Durov diagrams.

Groundwater from potable and irrigation water boreholes was also analyzed for trace elements. The iron content usually is within the drinking water standards $(<200 \mu \mathrm{gr} / \mathrm{l})$. In $7 \%(\mathrm{n}=17)$ of the sampled boreholes we observe a high iron content $(210-5500 \mu \mathrm{gr} / \mathrm{l})$. The manganese content in $14.5 \%(\mathrm{n}=33)$ of the boreholes ranges from 50 to $850 \mu \mathrm{gr} / \mathrm{l}$, exceeding drinking water standards $(50 \mu \mathrm{gr} / \mathrm{l})$. Relatively increased values $(1600-5600 \mu \mathrm{gr} / \mathrm{l}, \mathrm{n}=45)$ of boron, exceeding drinking water standards $(1000 \mu \mathrm{gr} / \mathrm{l})$ were determined in the groundwaters of Triglia- Tenedos to PlagiaSozopolis areas covering a surface of $100 \mathrm{~km}^{2}$. The arsenic content is usually low $(<5 \mu \mathrm{gr} / \mathrm{l})$ in general, however higher arsenic (11-3487 $\mu \mathrm{gr} / \mathrm{l})$ contents are found in the groundwaters of the same area as for high boron values. The elevated boron and arsenic values in the groundwaters are attributed to the contamination by geothermal waters $\left(33-35^{\circ} \mathrm{C}\right)$ from Katsika karst area. They have elevated contents of boron (4000-8000 $\mu \mathrm{gr} / \mathrm{l})$ and arsenic (500-3600 $\mu \mathrm{gr} / \mathrm{l})$ and infiltrate to the granular aquifers contaminating the fresh groundwater. The geothermal waters of Katsika karst area, besides the high values of $\mathrm{B}$ and As, contain also relatively high values of $\mathrm{EC}, \mathrm{Ca}, \mathrm{Cl}, \mathrm{HCO}_{3}$, $\mathrm{Na}, \mathrm{K}, \mathrm{F}, \mathrm{U}$ and $\mathrm{Li}$ (Veranis et al., 2010). The contents of other trace elements analyzed $(\mathrm{Cr}, \mathrm{Ni}, \mathrm{Al}$, $\mathrm{Co}, \mathrm{Pb}, \mathrm{Zn}, \mathrm{Cu}, \mathrm{Cd}, \mathrm{Sb}, \mathrm{Se}, \mathrm{U}, \mathrm{Rn})$ are within the permissible limits for the domestic water. The natural or anthropogenic contamination of areas in the aquifer system, have been defined by the hydrogeochemical research and these results must be taken into account for site selection of the drinking water boreholes.

Since the main groundwater uses of the aquifer system are for irrigation water we have evaluated the water quality for irrigation purposes. The most important characteristics of water which determine the suitability of groundwater for irrigation purpose are: Salinity, TDS, Relative Proportion of Sodium to other Cations (SAR), $\mathrm{HCO}_{3}$ content, Residual Sodium Carbonate (RSC), the values of sodium percentage ( $\mathrm{Na} \%)$. Permeability Index (P.I) and trace elements such as B, As, F, Cu, Fe, Mn, Mo, Al, Cr, Co, Li, Sb, Ni, V, Zn, Pb (EPA 2004). In 96\% of the boreholes analyzed the waters are suitable for irrigation water purposes (Veranis et al., 2010).

\section{Conclusions}

The aquifer system of west Chalkidiki area $\left(667 \mathrm{~km}^{2}\right)$ is a multilayered system semi-confined to confined, consisting of unconsolidated to semi-consolidated sands, gravels, conglomerates, sandstones and marly limestones with intercalations of impermeable to semi-permeable beds of red clays and marls or a mixture of them. The aquifer system hydrocapacity is of medium to moderate potential. 
The geometric mean value of borehole $(\mathrm{n}=150)$ yields is $40 \mathrm{~m}^{3} / \mathrm{h}(10-140)$, specific capacity (Sc) is $1.50\left(\mathrm{~m}^{3} / \mathrm{h}\right) / \mathrm{m}(0.08-33.3)$, transmissivity $(\mathrm{T})$ is $5.0 * 10^{-4} \mathrm{~m}^{2} / \mathrm{s}\left(3.46 * 10^{-5}-2.92 * 10^{-2}\right)$ and hydraulic conductivity $(\mathrm{K})$ is $1.56 * 10^{-5} \mathrm{~m} / \mathrm{s}\left(3.30 * 10^{-7}-1.01 * 10^{-3}\right)$ respectively. The groundwater abstractions are $74 * 10^{6} \mathrm{~m}^{3} / \mathrm{yr}$. Based on data of piezometric studies carried out in the period 2003-14, it is concluded that the piezometric surface decline is located in Kalyvia-Agios Mammas, PortariaDionysiou, Akrotiri Epanomi and Agelochori coastal areas and resulted to salinization of the coastal area aquifers. In the rest Central and NW part of the aquifer system we have noticed a positive water balance relation between the aquifers recharge and water pumping quantities or the recharge is higher than the pumped water quantities.

Groundwater has generally a good quality, with the exception of Triglia-Tenedos-Plagia- SozopoliSilata area $\left(100 \mathrm{~km}^{2}\right)$ where the ground water contains high values of As (3400-10 $\left.\mu \mathrm{gr} / \mathrm{l}\right)$, B (4.0-1.5 $\mathrm{mg} / \mathrm{l}) \pm \mathrm{Cl}(200-250 \mathrm{mg} / \mathrm{l})$. Other common natural contaminants exceeding the recommended drinking water standards are iron (210-5500 $\mu \mathrm{gr} / \mathrm{l})$ and manganese $(50-850 \mu \mathrm{gr} / \mathrm{l})$ corresponding to $7 \%$ and $14.5 \%$ of the analyzed samples respectively. High values of nitrate $(50-208 \mathrm{mg} / \mathrm{l})$ are located in some boreholes in Moudania-Portaria and Akrotiri Epanomi areas.

From the total area of the aquifer system $\left(667 \mathrm{~km}^{2}\right)$, it can be concluded that exploitable groundwater reserves are found in $510 \mathrm{~km}^{2}$ and about $300 \mathrm{~km}^{2}$ contain potable groundwaters. Since the water balance in the most part of the aquifer system is negative, it is necessary to protect the groundwater reserves by constructing a dam in the Olynthios river in order to eliminate the groundwater consumptions.

\section{References}

ENM and Consultants, 2008. Developing water resources management plans of West Macedonia, Central Macedonia and Thraki Regions, Northern Greece. Water resources management plans of the water districts (SAE061/3-20002 SE06130000), Special Secretary of Water Resources, Athens, Unp. report (in Greek).

EPA, 2004. Guidelines for Water Reuse, Washington, DC, 450 pp.

Hounslow, A., 1995. Water Quality Data: Analysis and Interpretation, Lewis Publ., 416 pp.

Loehnert, E. and Papakonstantinou, A., 1988. Relationship between karst and porous aquifers on the Chalkidiki peninsula, In: Greece, IAH 21rst Congress on Karst hydrogeology and karst environmental protection, Beijing, China, 321-326.

Soulios, G., 2004. General Hydrogeology, STUDIO PRESS, Thessaloniki, 374 pp.

Syrides, G., 1990. Lithostratigraphic, biostratigraphic and paleogeographic study of the NeogeneQuaternary sedimentary deposits of Chalkidiki Peninsula, Northern Greece, Ph Degree study, Geological Department, Aristotle University, Thessaloniki, 340 pp. (in Greek).

Wolff, G., 1982. Physical Properties of rocks-Porosity, Permeability, Distribution Coefficient and Dispersivity, U.S. Geol. Survey, Open file Report 1982, 82-116, 118 pp.

Xefteris, A., 2000. Study of quality degradation of ground water in Kalamaria plain with empha sis to nitrate contamination, PhD Degree, AUTH, Civil Eng. Department, 309 pp.

Veranis, N., Kalousi, E., Lazaridou, M., Pratanopoulos, A. and Chatzikyrkou, A., 2010. Hydrogeological Study of the aquifer systems of Central Macedonia Region, CSF Project (2003-2009) "Inventory and Assessment of Hydrogeological Character of the aquifer systems of the country", RUCM-IGME, 15 issues, maps (in Greek). 